\title{
Public Tertiary Education Expenditure in Portugal: a Non-Parametric Efficiency Analysis ${ }^{1}$
}

António Afonso ${ }^{2}$ and Mariana Santos ${ }^{3}$

May 2004

\begin{abstract}
We employ a non-parametric methodology, Data Envelopment Analysis, to estimate efficiency scores for Portuguese public universities for 2001. Due to the tertiary education organisational features we consider universities as well as faculties and institutes as decision entities. Using frontier analysis we are able to separate universities/faculties/institutes that might qualify, as "performing well" from those were some improvement might increase its efficiency. This is a first effort of checking efficiency and productivity in Portuguese public tertiary education using nonparametric analysis.
\end{abstract}

JEL: C14, H52, I21, I28

Keywords: expenditure in tertiary education, efficiency, production possibility frontier, DEA

\footnotetext{
${ }^{1}$ We are grateful to Miguel St. Aubyn for helpful comments. Any remaining errors are the responsibility of the authors. The opinions expressed herein are those of the authors and do not necessarily reflect those of the author's employers.

${ }^{2}$ ISEG/UTL - Technical University of Lisbon, CISEP - Research Centre on the Portuguese Economy, R. Miguel Lúpi 20, 1249-078 Lisbon, Portugal, email: aafonso@iseg.utl.pt.

${ }^{3}$ Economic Research and Forecasting Department, Ministry of Finance, R. da Alfândega, 5, $2^{\circ}, 1100-$ 016 Lisbon, Portugal, email: marianaroque@dgep.pt.
} 


\section{Contents}

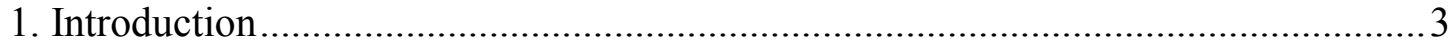

2. Stylised facts on public tertiary education in Portugal .......................................... 4

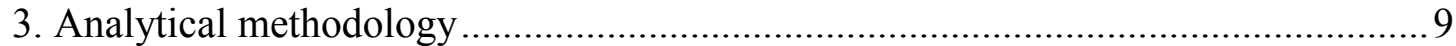

4. Non-parametric efficiency analysis of tertiary spending in Portugal ...................... 15

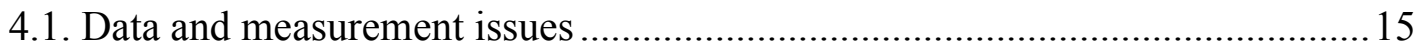

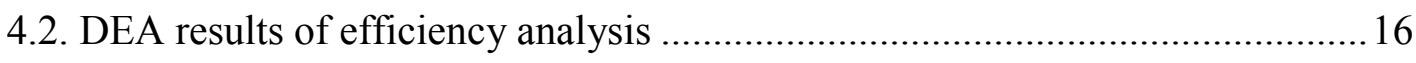

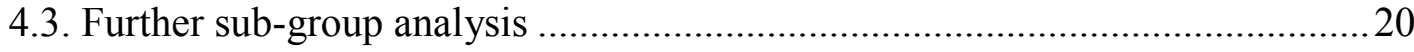

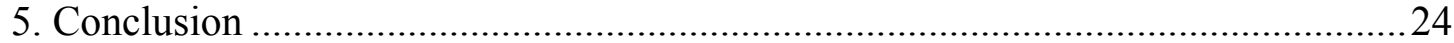

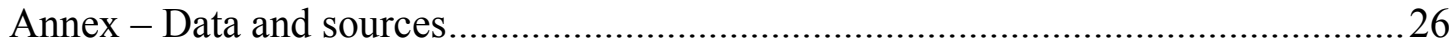

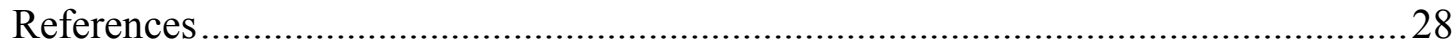




\section{Introduction}

As Blanchard (2004) points out, good performance in higher education is expected to produce positive growth effects, and tertiary education in many European countries still lags behind the level achieved in other developed economies. On the other end, there is the overall idea, alleged by some academic work and held in reports from international organisations, that the public sector remains inefficient in most European countries. These two factors seem sufficient motivation to address the issue of the efficiency of public tertiary expenditure in Portugal.

The proper measurement of public sector performance, particularly when it concerns services provision, is a delicate empirical issue and the related literature, principally when it comes to aggregate data, is still limited. This measurement issue is here considered in terms of efficiency measures comparing public resources - total expenditures, dimension of staff - used by Portuguese public universities, and straightforward measure and/or indicator of the universities' output, typically the number of students enrolled, both taking into consideration undergraduate and postgraduate students. To our knowledge no similar previous study exists for this specific universe. Furthermore, we are only aware of related papers by Coelli (1996) for Australian universities and by Førsund and Kalhagen (1999) for regional colleges in Norway.

This paper contributes to the literature by analysing the efficiency of resources used by Portuguese public universities to provide their services. With the use of frontier analysis we focus on how close public universities are to operating on the efficiency frontier. We study public expenditure efficiency of Portuguese universities in 2001 by applying a non-parametric methodology, Data Envelopment Analysis (DEA), to a set of 45 public universities/faculties/institutes and also to a sub-set of 36 faculties/institutes.

The remainder of the paper is organised as follows. Section 2 presents some stylised facts concerning tertiary spending in Portugal. Section 3 briefly addresses the DEA methodology. Section 4 explains the data and discusses the empirical results of the efficiency analysis, while section 5 concludes this study. 


\section{Stylised facts on public tertiary education in Portugal}

The tertiary education sector in Portugal has traditionally been a public one. Only in the last decade privately run universities started to provide a more consistent alternative thereby increasing the offer of available places for students in the tertiary education level. Nevertheless, and since data regarding private tertiary education institutions, namely concerning total expenditures, are not easy to come across from a unified source, we will only address the public segment (by far the larger) of the tertiary education sector.

Portuguese tertiary public sector includes both Universities and the so-called "Institutos Politécnicos." While the Politécnicos have been more oriented to 3-year courses, Universities offer 4 or 5-year graduate courses, and they are also entitled to give Masters and PhD courses. ${ }^{4}$ Again, in our analysis, only Universities will be used, and we allow for some sensitivity analysis of the results taking account of both graduation and postgraduation students in the calculations.

Additionally, there are also tertiary education courses provided by military institutions and by the Portuguese Catholic University. Given the particularities of such institutions, data availability, and also in order to keep the sample as homogeneous as possible, those institutions are not included in the sample.

The number of places available in tertiary education is determined every year by the institutions and approved by the government. All courses have a numerus clausus fixed by each institution according to its capacity. Additionally, Faculties and Institutes have to specify a minimum entrance requirement for their various courses. ${ }^{5}$

\footnotetext{
${ }^{4}$ The academic degrees confered by Portuguese Universities are the following: graduation or first degree (usually 4-5 years); Masters degree (includes writing a thesis); $\mathrm{PhD}$ degree (includes writing a thesis); and aggregation.

${ }^{5}$ There are national competitive examinations for the canditates with satifactory school and exam results. The candidates' marks have to be above a minimum set by each institution. For some courses (music, sports) selection is on the basis of ability.
} 
According to the 2001 figures, our sample of public universities covers 75 per cent of the global number of students in public, military, or private universities (see Figure 1). Moreover, and in what concerns postgraduate students, our sample covers around 86 per cent of total masters students in 2001.

Between 1997 and 2001, the overall number of graduation students in the tertiary education level increased 13.9 per cent (see Figure 1), roughly 3.3 per cent per year. This implies overall increases in the 1997-01 period of 10.4 per cent in the public universities and of 60.5 per cent in the public "Politécnicos". There were opposite changes in the number of students over that period in private and co-operative universities, $-9,9$ per cent, in the Portuguese Catholic University, -4.8 per cent, and in the other private and co-operative institutions, -6.3 per cent.

Figure 1 - Undergraduate students in Portuguese tertiary education sector (1997-2001)

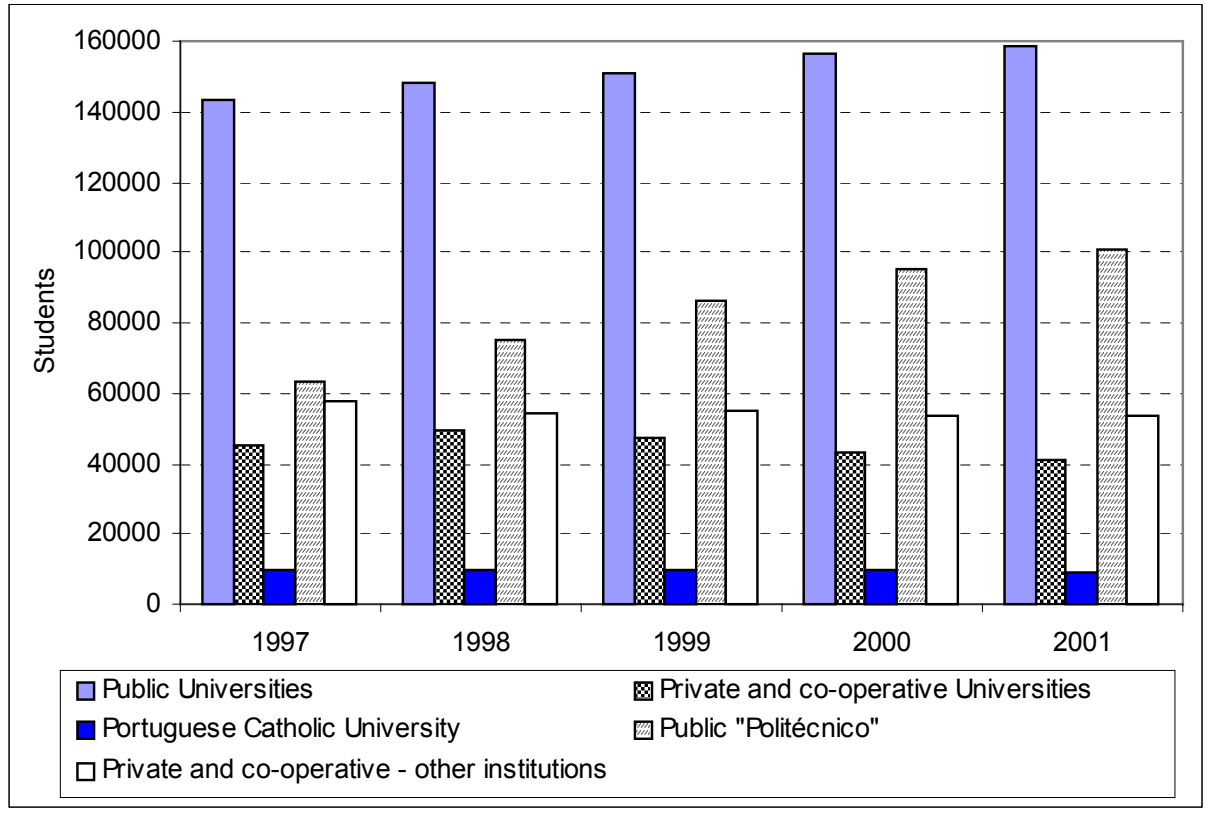

Source: Direcção-Geral do Ensino Superior.

Notes: Public Universities includes military universities. Public "Politécnico" includes military institutions.

In terms of comparison within the EU, the proportion of students enrolled in tertiary education in Portugal, as percentage of all pupils and students, 17 per cent, was above the EU average in 1999/2000, 15 per cent (see Figure 2). Indeed, and accompanying the overall trend in the EU, the number of students in tertiary education more than 
doubled over the last 25 years. ${ }^{6}$ More precisely in Portugal, over four times as many students were enrolled in 1999/2000 as in 1975/76, making it the country with the greatest growth in the EU.

Figure 2 - Students in tertiary education, as \% of all students, 1999/2000

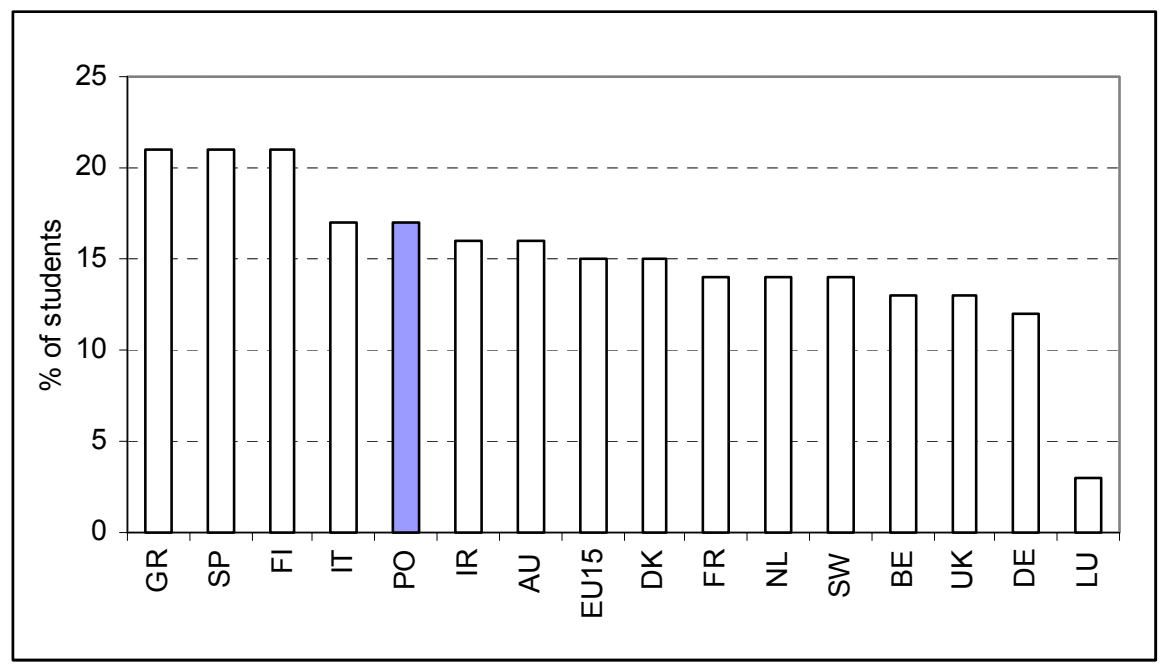

Source: Eurostat (2002).

However, if one considers, for instance, the percentage of population between 30 and 34 years, that hold a tertiary education qualification in 2000 , this percentage was only 11.3 per cent in Portugal, well below the 24.6 per cent in the EU15 (see Figure 3).

Figure 3 - Proportion of population aged between 30 and 34 with tertiary education qualifications, 2000

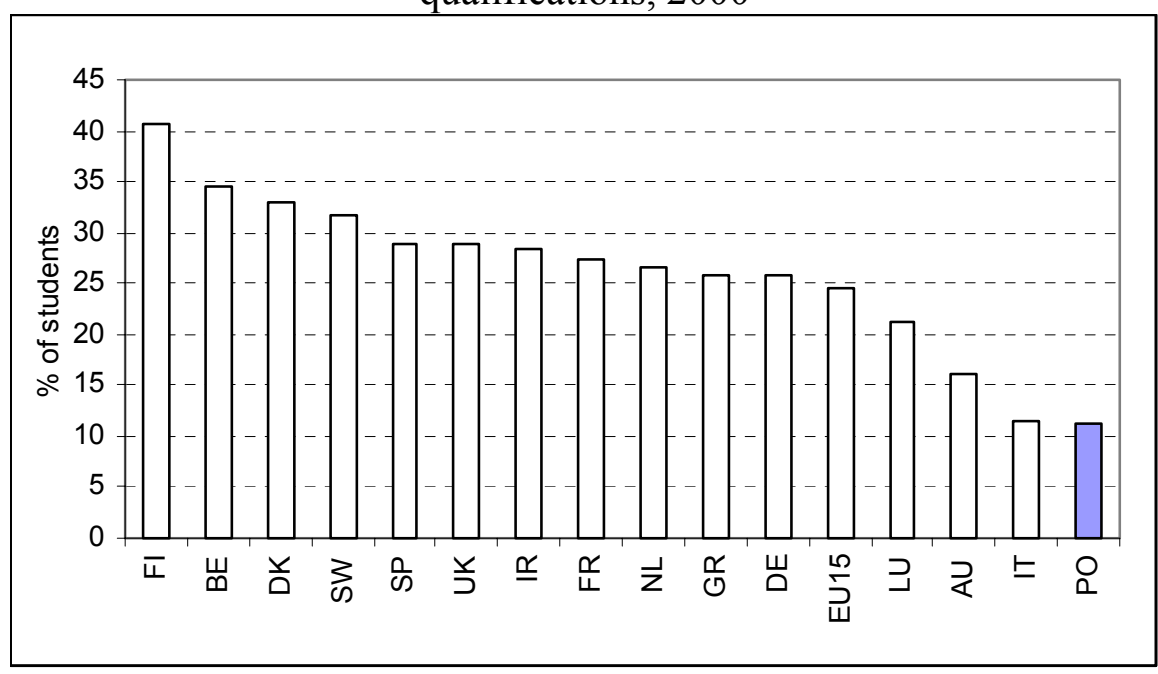

Source: Eurostat (2002).

${ }^{6}$ See Eurostat (2002). 
During the period 1997-2001, the overall number of teachers in public universities in Portugal increased around 9.8 per cent. On a broader perspective, one may notice that the number of teachers increased by 31.7 per cent between 1990 and 2001 (see Figure 4 ), some 2.5 per cent every year.

Figure 4 - Teachers in public universities (1990-2001)

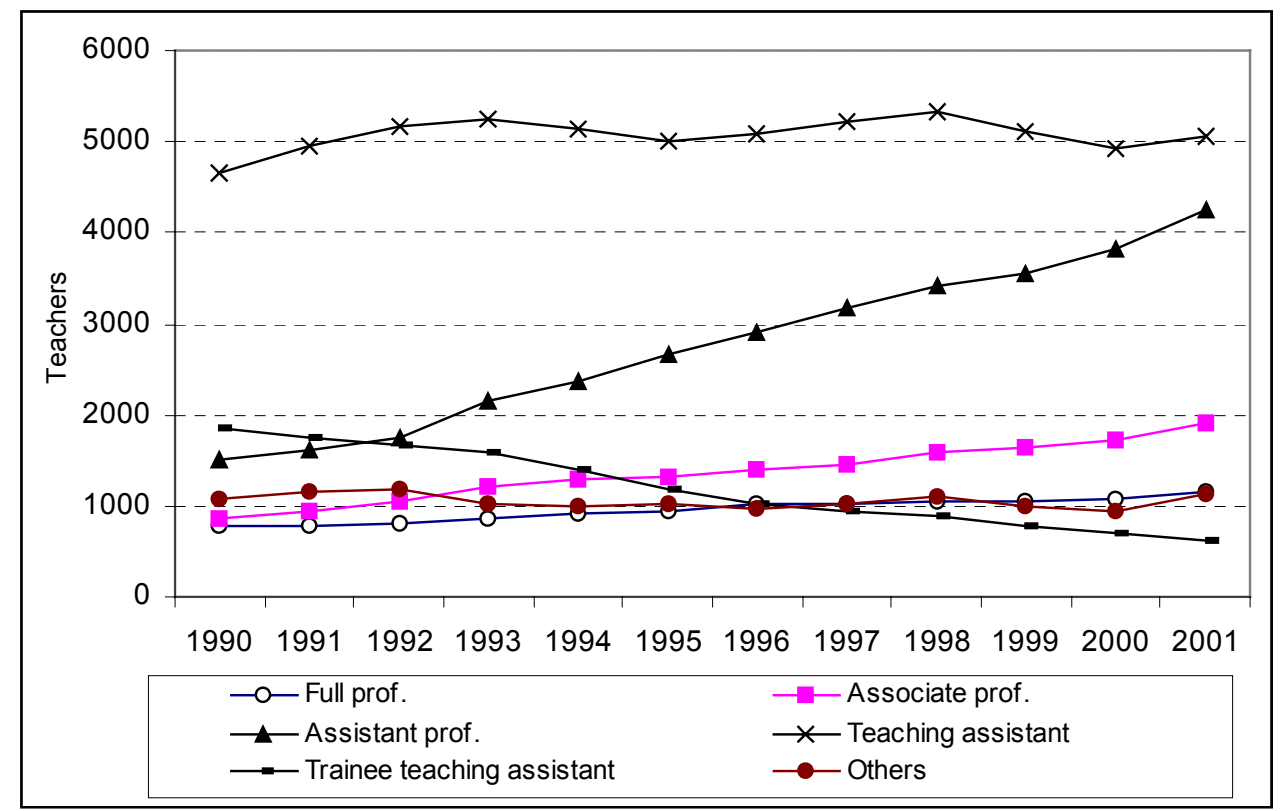

Source: Direcção-Geral do Ensino Superior.

Another interesting point to make concerning the structure of public universities' teachers is the fact there are too few full professors and too many assistant professors (see Figure 5). 
Figure 5 - Structure of teachers' levels in public universities: 1990, 2001

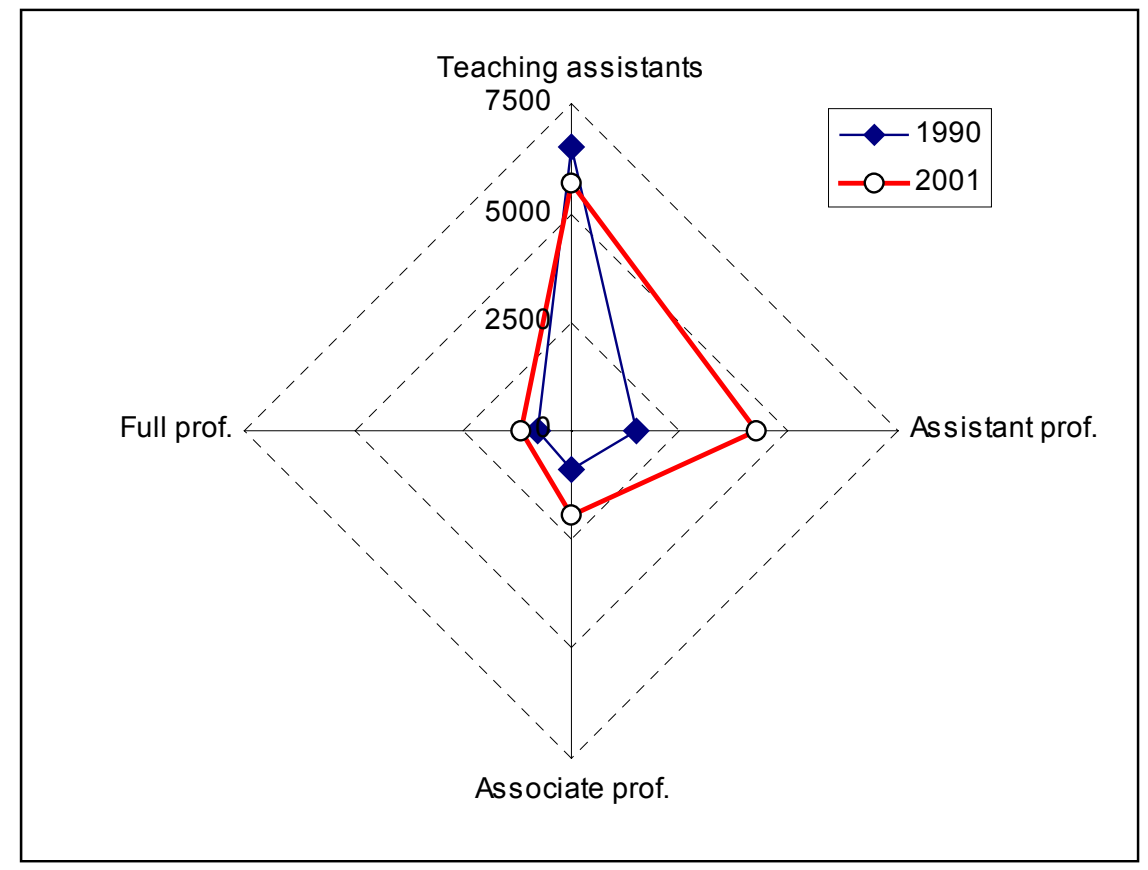

Source: Direcção-Geral do Ensino Superior.

Note: Teaching assistants include trainee-teaching assistants.

This feature of tertiary education in Portugal is also pointed out by Athans (2002), who, when comparing two engineering departments in the US (MIT) and in Portugal (IST-UTL), mentions that in typical US research universities the "academic pyramid" is inverted. Indeed, and even if between 1990 and 2001, there was, in the current Portuguese public university system, a decrease at the teaching assistants level, and a clear increase at the assistant professor level, the top three categories still clearly reproduced a standard pyramid in 2001 (see Figure 6). 
Figure 6 - Professors pyramid in the Portuguese public university system: 2001

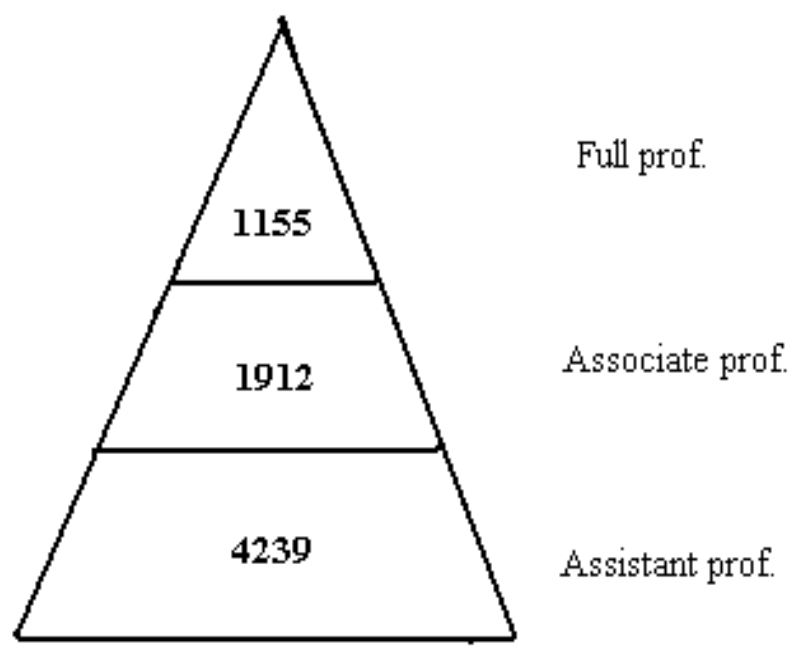

\section{Analytical methodology}

We use a non-parametric method that allows the estimation of efficiency frontiers and efficiency losses - Data Envelopment Analysis (DEA). This method was originally developed and applied to firms that convert inputs into outputs. Coelli, Rao and Battese (1998) and Sengupta (2000) introduce the reader to this literature and describe several applications. ${ }^{7}$

The term "firm", sometimes replaced by the more encompassing Decision Making Unit (henceforth DMUs), the term coined by Charnes et al. (1978), may include nonprofit or public organisations, such as hospitals, universities or local authorities. For instance, De Borger and Kerstens (1996) analyse the efficiency of Belgian local governments.

On related work, Gupta and Verhoeven (2001) use FDH analysis to measure the efficiency of government expenditure on education and health in a set of countries in Africa. Clements (2002) assessed the efficiency of education spending in the European Union. St. Aubyn (2002) reports results of FDH analysis applied to

7 An possible alternative non-parametric method would be Free Disposable Hull analysis (FDH). Deprins, Simar, and Tulkens (1984) first proposed the FDH analysis, which relaxes the convexity assumption maintained by the DEA model. For an overview of the FDH analysis see for instance Tulkens (1993). 
education and health spending in OECD countries. Afonso, Schuknecht and Tanzi (2003) studied public spending efficiency for the OECD countries using composite indicators, and Afonso and St. Aubyn (2004) use both FDH and DEA for a crosscountry analysis of efficiency in education and health.

The general relationship that we expect to test, regarding efficiency in tertiary education, can be given by the following function for university $i$ :

$$
Y_{i}=f\left(X_{i}, Z_{i}\right), i=1, \ldots, n
$$

where we have $Y_{i}$ - set of indicators reflecting education output; $X_{i}$ - spending on university $i$, either per student or in some other measure; $Z_{i}-$ control variables, both quantitative and socio-economic education related variables.

Data Envelopment Analysis, originating from Farrell's (1957) seminal work and popularised by Charnes, Cooper and Rhodes (1978), assumes the existence of a convex production frontier, a hypothesis that is not required for instance in the FDH approach. The production frontier in the DEA approach is constructed using linear programming methods. The terminology "envelopment" stems out from the fact that the production frontier envelops the set of observations. ${ }^{8}$

In this sub-section we illustrate the DEA framework with the calculation of technical efficiency measures by using an input-oriented example. The purpose of an inputoriented example is to study by how much input quantities can be proportionally reduced without changing the output quantities produced.

Alternatively, and by computing output-oriented measures, one could also try to assess how much output quantities can be proportionally increased without changing the input quantities used. The two measures provide the same results under constant returns to scale but give different values under variable returns to scale. Nevertheless,

\footnotetext{
${ }^{8}$ Coelli et al. (1998) and Thanassoulis (2001) offer good introductions to the DEA methodology, while Simar and Wilson (2003) and Murillo-Zamorano (2004) are good references for an overview of frontier techniques.
} 
and since the computation uses linear programming, not subject to statistical problems such as simultaneous equation bias and specification errors, both output and inputoriented models will identify the same set of efficient/inefficient producers or DMUs. ${ }^{9}$

The analytical description of the linear programming problem to be solved, in the constant-returns to scale hypothesis, is sketched below. Suppose there are $k$ inputs and $m$ outputs for $n$ DMUs. For the i-th DMU, $y_{i}$ is the column vector of the inputs and $x_{i}$ is the column vector of the outputs. We can also define $X$ as the $(k \times n)$ input matrix and $Y$ as the $(m \times n)$ output matrix. The DEA model is then specified with the following mathematical programming problem, for a given i-th DMU: ${ }^{10}$

$$
\begin{gathered}
\min _{\theta, \lambda} \theta \\
\text { s. to } \quad-y_{i}+Y \lambda \geq 0 \\
\theta x_{i}-X \lambda \geq 0 . \\
n 1^{\prime} \lambda=1 \\
\lambda \geq 0
\end{gathered}
$$

In problem (2), $\theta$ is a scalar (that satisfies $\theta \leq 1$ ), more specifically it is the efficiency score that measures technical efficiency. It measures the distance between a university and the efficiency frontier, defined as a linear combination of best practice observations. With $\theta<1$, the university is inside the frontier (i.e. it is inefficient), while $\theta=1$ implies that the university is on the frontier (i.e. it is efficient).

The vector $\lambda$ is a $(n \times 1)$ vector of constants that measures the weights used to compute the location of an inefficient DMU if it were to become efficient. The inefficient DMU would be projected on the production frontier as a linear combination of those weights, related to the peers of the inefficient DMU. The peers are other DMUs that are more efficient and therefore are used as references for the inefficient DMU. $n 1$ is a n-dimensional vector of ones. The restriction $n 1^{\prime} \lambda=1$ imposes convexity of the

\footnotetext{
${ }^{9}$ In fact, and as mentioned namely by Coelli et al. (1998), the choice between input and output orientations is not crucial since only the two measures associated with the inefficient units may be different between the two methodologies.

${ }^{10}$ We simply present here the equivalent envelopment form, derived by Charnes et al. (1978), using the duality property of the multiplier form of the original programming model.
} 
frontier, accounting for variable returns to scale. Dropping this restriction would amount to admit that returns to scale were constant. Notice that problem (2) has to be solved for each of the $n$ DMUs in order to obtain the $n$ efficiency scores.

We use an example with five universities that teach courses to students by using two inputs: the number of teachers and the value of spending used. The universities produce a single output, the number of students enrolled. We adopt in our example an input-oriented method because we assume that management and economic decisionmakers have more control over inputs than over outputs. Table 1 reports the data used for the example.

Table 1 - One output, two input example for 5 universities

\begin{tabular}{cccccc}
\hline \multirow{2}{*}{ University } & Output & \multicolumn{2}{c}{ Inputs } & \multicolumn{2}{c}{ Input/output ratios } \\
\cline { 3 - 6 } & Students $(Y)$ & Spending $(X 1)$ & Teachers $(X 2)$ & $X 1 / Y$ & $X 2 / Y$ \\
\hline A & 100 & 200 & 50 & 2.0 & 0.5 \\
B & 200 & 200 & 40 & 1.0 & 0.2 \\
C & 300 & 750 & 60 & 2.5 & 0.2 \\
D & 200 & 500 & 20 & 2.5 & 0.1 \\
E & 100 & 200 & 20 & 2.0 & 0.2 \\
\hline
\end{tabular}

Assuming, for instance, constant-returns to scale (CRS) we can plot the DEA frontier on a two-dimensional diagram, using the input/output ratios in the axis, as in Figure 7. Notice that the DEA frontier actually envelops all the available data points. All points that lie on the frontier are efficient while all points that lie within the frontier are inefficient. 
Figure 7 - DEA example: one output, two inputs (input-oriented) for 5 universities (CRS)

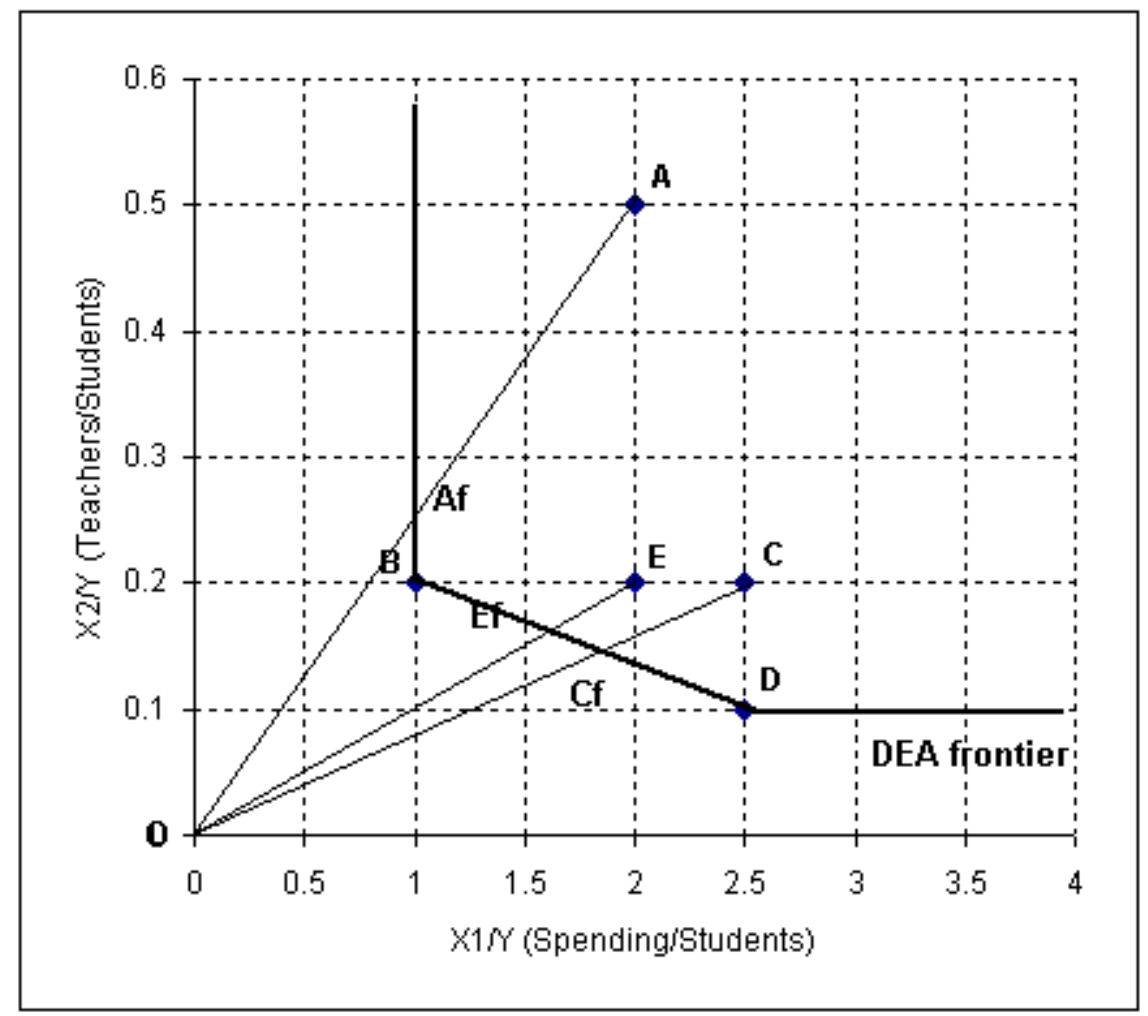

The technical efficiency of a university is measured along a ray from the origin, $\mathrm{O}$, to the point that represents that university in the diagram. ${ }^{11}$ For instance, the efficiency of say university $\mathrm{C}$ is the ratio of the distance from the origin, point $\mathrm{O}$, to point $\mathrm{Cf}$ (on the frontier), over the distance from the origin to point $\mathrm{C}$. In other words the efficiency of university $\mathrm{C}$ is given by $\mathrm{OCf} / \mathrm{OC}=0.727$. Therefore, university $\mathrm{C}$ should be able to proportionally reduce the consumption of all inputs by $27.3 \%$ without reducing output. This would imply production at point $\mathrm{Cf}$ in Figure 7.

Observe that the projected point Cf on the DEA frontier is located in the segment of the frontier that connects universities B and D. In the literature these two universities would be referred as the peers of university $\mathrm{C}$ since they give the efficient production for university $\mathrm{C}$. Indeed, point $\mathrm{Cf}$ is a linear combination of points $\mathrm{B}$ and $\mathrm{D}$ and, as we

\footnotetext{
${ }^{11}$ As proposed by Farrell (1957), technical efficiency is one of the two components of total economic efficiency, also referred to as X-efficiency. The second component is allocative efficiency and they are put together in the overall efficiency relation: economic efficiency $=$ technical efficiency $\times$ allocative efficiency (see Coelli et al. (1998) and Thanassoulis (2001) for details). A DMU is technically efficient if it is able to obtain maximum output from a set of given inputs (output-oriented) or is capable to minimise inputs to produce the same level of output (input-oriented measures). On the other hand allocative efficiency reflects the DMUs ability to use the inputs in optimal proportions.
} 
already mentioned, the weights are obtained from solving the linear programming problem (2) for university $\mathrm{C}$.

Table 2 summarises the results of solving the 5 linear programming problems for our five-university example. ${ }^{12}$ Notice that both universities B and D are efficient since they have technical efficiency scores of 1.0, and they are themselves peers and are located on the DEA frontier. On the other hand, universities $\mathrm{A}, \mathrm{C}$ and $\mathrm{E}$ are not efficient and are enveloped by the DEA frontier.

Table 2 - One output, two input example for 5 universities, input-oriented constant returns to scale

\begin{tabular}{ccccccc}
\hline University & $\theta$ & $\lambda_{A}$ & $\lambda_{B}$ & $\lambda_{C}$ & $\lambda_{D}$ & $\lambda_{E}$ \\
\hline A & 0.500 & - & 0.500 & - & - & - \\
B & 1.000 & - & 1.000 & - & - & - \\
C & 0.727 & - & 0.682 & - & 0.818 & - \\
D & 1.000 & - & - & - & 1.000 & - \\
E & 0.800 & - & 0.300 & - & 0.200 & - \\
\hline
\end{tabular}

Returning to the case of inefficient university $\mathrm{C}$, we can now more precisely determine the changes in the use of inputs that would be necessary for this university to become efficient and to be located on the DEA frontier. Table 3 summarises the results for our university $\mathrm{C}$, and also reports the radial movements in terms of reduction in the inputs.

Table 3 - One output, two input example, input-oriented constant returns to scale, summary results for university $\mathrm{C}$

\begin{tabular}{lcrr}
\hline \multicolumn{1}{c}{ University C } & \multicolumn{1}{c}{$\begin{array}{c}\text { Original } \\
\text { values }\end{array}$} & $\begin{array}{c}\text { Radial } \\
\text { movement }\end{array}$ & $\begin{array}{c}\text { Projected } \\
\text { (target) values }\end{array}$ \\
\hline Students (Y) & 300.000 & 0.000 & 300.000 \\
Spending (X1) & 750.000 & -204.750 & 545.250 \\
Teachers (X2) & 60.000 & -16.380 & 43.620 \\
\hline
\end{tabular}

Using the efficiency score of 0.727 , the target input ratios of university $\mathrm{C}$ would be then computed as $0.727 \times[2.5 ; 0.2]=[1.818 ; 0.145]$. This implies a radial shift of university $\mathrm{C}$ towards point $\mathrm{Cf}$ on the DEA frontier. To "produce" the same amount of output, 300 students, and to be efficient, university $\mathrm{C}$ would then need to use the

\footnotetext{
${ }^{12}$ In implementing DEA, we follow procedures proposed by Coelli et al. (1998) and use the computer software DEAP 2.1 provided by Coelli et al. (1998).
} 
following units of both inputs: $300 \times[1.818 ; 0.145]=[545.250 ; 43.620]$. In other words, it would be enough to use only 545 units of spending (instead of 750) and 44 teachers (instead of 60).

\section{Non-parametric efficiency analysis of tertiary spending in Portugal}

\subsection{Data and measurement issues}

In our study we assess the efficiency of 45 Portuguese public universities in 2001. More precisely, we use data for faculties, institutes or simply for the whole university, depending on the data segregation. Therefore, we collected data for 36 faculties (or institutes), while for 9 DMUs (universities) only aggregated data was available and not by faculty. ${ }^{13}$ All these DMUs are listed in the Annex alongside with a short code name, useful to identify each faculty in terms of the results.

The way we choose our DMUs stems from the fact that most public universities in Portugal aggregate several faculties or institutes, depending on the organisational framework adopted. For instance, in the Technical University of Lisbon there are 7 Institutes that teach, broadly speaking, courses on economics, engineering, architecture, veterinary, agronomy, political and social sciences, and sports. Other universities aggregate faculties instead of institutes as for instance the University of Porto or the University of Lisbon. Still other universities do not have a fully-fledged segmentation either in terms of institutes or in terms of faculties.

This said, our DMUs are both primarily faculties and institutes. This segregation of DMUs can also be found in the Annual State General Account (Conta Geral do Estado) taking into account the relative autonomy of the several the autonomous bodies of the Central Government. At the time of writing, 2001 is the last year when the Annual State General Account is available, and therefore the only publicly available homogeneous source of total spending in public university.

\footnotetext{
${ }^{13}$ In the empirical analisys we also put ISCTE on the Universities group even if it is not an University, but simply because data is agreggated for this institute, covering a quite large number of courses, and we want to have some homogeneous DMUs.
} 
Concerning the selection of outputs and inputs, as a general rule of thumb there should be at least three DMUs for each input and output variable used in the model. This allows having sufficient degrees of freedom when implementing the DEA methodology. ${ }^{14}$ Therefore, and since we have 45 DMUs (or 36, considering only Faculties and Institutes) we could easily have used a total number of say 5 or 6 inputs and outputs. Additionally we need relatively homogeneous DMUs, with the same inputs and outputs in positive amounts. A missing value for either inputs or outputs consequently implies dropping the respective DMU from the set.

Data limitations prevented us from using such performance (output) measures as graduation rate. Additionally, course specifically related data also proved rather difficult to collect. As it stands, we used as a measure of output the number of students enrolled in 2001, taking into account both graduate and postgraduate students. For our inputs we selected, and again due to data constraints, total spending (as reported in the 2001 Annual State General Account) and the total number of teachers, again for 2001. This basically means that we performed our DEA analysis in a two-input one-output framework. Additionally, one may mention that our selected input and output measures are rather similar to the ones used by Coelli (1996) for the Australian Universities case. An immediate caveat relates to the fact that some degree of correlation cannot be avoided among the inputs used.

\subsection{DEA results of efficiency analysis}

In Table 4 we present the DEA variable-returns-to-scale technical efficiency results using a two-input one-output framework. We use a financial input, total expenditures in 2001, and a quantitatively measured input, the number of teachers in 2001. Additionally, and as a measure of comparison, we also present the constant returns to scale results.

\footnotetext{
${ }^{14}$ Indeed, with less than three DMUs per input and output there is the risk that too many DMUs will turn out to be efficient (see Bowlin (1998)).
} 
Table 4 - DEA results for tertiary education efficiency in Portugal, 2 inputs (total expenditures in 2001, and number of teachers in 2001) and 1 output (enrolment rate, 2001)

\begin{tabular}{|c|c|c|c|c|c|c|c|c|c|c|}
\hline \multirow{3}{*}{$\begin{array}{c}\text { University/ } \\
\text { Faculty/ } \\
\text { Institute }\end{array}$} & \multicolumn{5}{|c|}{ Enrolment: graduates } & \multicolumn{5}{|c|}{ Enrolment: graduates and postgraduates * } \\
\hline & \multicolumn{2}{|c|}{ Input oriented } & \multicolumn{2}{|c|}{ Output oriented } & \multirow[t]{2}{*}{ CRS TE } & \multicolumn{2}{|c|}{ Input oriented } & \multicolumn{2}{|c|}{ Output oriented } & \multirow[t]{2}{*}{ CRS TE } \\
\hline & VRS TE & Rank & VRS TE & Rank & & VRS TE & Rank & VRS TE & Rank & \\
\hline UA & 0.090 & 31 & 0.023 & 45 & 0.003 & 0.103 & 31 & 0.023 & 45 & 0.003 \\
\hline UAL & 0.058 & 37 & 0.045 & 44 & 0.004 & 0.067 & 34 & 0.045 & 44 & 0.004 \\
\hline UAV & 0.032 & 44 & 0.067 & 43 & 0.003 & 0.036 & 44 & 0.067 & 43 & 0.003 \\
\hline UBI & 0.061 & 35 & 0.089 & 42 & 0.007 & 0.066 & 35 & 0.090 & 42 & 0.007 \\
\hline UC-FCT & 0.039 & 41 & 0.111 & 41 & 0.006 & 0.043 & 41 & 0.111 & 41 & 0.006 \\
\hline UE & 0.037 & 43 & 0.133 & 40 & 0.006 & 0.039 & 42 & 0.133 & 40 & 0.007 \\
\hline UL-FL & 0.061 & 36 & 0.158 & 39 & 0.012 & 0.061 & 37 & 0.158 & 39 & 0.012 \\
\hline UL-FD & 0.150 & 28 & 0.186 & 38 & 0.033 & 0.150 & 28 & 0.186 & 38 & 0.033 \\
\hline UL-FM & 0.237 & 25 & 0.212 & 37 & 0.067 & 0.264 & 22 & 0.214 & 37 & 0.066 \\
\hline UL-FC & 0.050 & 40 & 0.222 & 36 & 0.015 & 0.054 & 40 & 0.222 & 36 & 0.015 \\
\hline UL-FF & 0.239 & 24 & 0.257 & 35 & 0.077 & 0.260 & 23 & 0.262 & 35 & 0.080 \\
\hline UL-FPCE & 0.263 & 21 & 0.287 & 34 & 0.092 & 0.260 & 24 & 0.290 & 34 & 0.087 \\
\hline UL-FMD & 0.631 & 11 & 0.336 & 33 & 0.259 & 0.757 & 9 & 0.337 & 33 & 0.273 \\
\hline UL-FBA & 0.254 & 23 & 0.350 & 31 & 0.099 & 0.254 & 25 & 0.350 & 31 & 0.099 \\
\hline UM & 0.120 & 30 & 0.345 & 32 & 0.054 & 0.132 & 30 & 0.346 & 32 & 0.055 \\
\hline UMI & 0.019 & 45 & 0.356 & 30 & 0.009 & 0.020 & 45 & 0.356 & 30 & 0.009 \\
\hline UNL-FCT & 0.051 & 39 & 0.378 & 29 & 0.026 & 0.057 & 39 & 0.378 & 29 & 0.027 \\
\hline UNL-FCSH & 0.069 & 34 & 0.409 & 28 & 0.035 & 0.065 & 36 & 0.409 & 28 & 0.033 \\
\hline UNL-FD & 0.787 & 8 & 0.522 & 25 & 0.416 & 0.787 & 8 & 0.522 & 25 & 0.416 \\
\hline UNL-FE & 0.183 & 27 & 0.464 & 27 & 0.105 & 0.189 & 27 & 0.465 & 27 & 0.105 \\
\hline UNL-FCM & 0.277 & 20 & 0.501 & 26 & 0.183 & 0.332 & 15 & 0.507 & 26 & 0.193 \\
\hline UNL-ISEGI & 1.000 & 1 & 1.000 & 1 & 0.694 & 0.890 & 6 & 0.598 & 21 & 0.544 \\
\hline UP-FL & 0.075 & 33 & 0.525 & 24 & 0.048 & 0.075 & 33 & 0.525 & 24 & 0.048 \\
\hline UP-FD & 0.746 & 9 & 0.658 & 20 & 0.497 & 0.746 & 10 & 0.658 & 19 & 0.497 \\
\hline UP-FM & 0.260 & 22 & 0.592 & 22 & 0.199 & 0.269 & 21 & 0.595 & 22 & 0.187 \\
\hline UP-FC & 0.079 & 32 & 0.588 & 23 & 0.060 & 0.082 & 32 & 0.590 & 23 & 0.059 \\
\hline UP-FE & 0.055 & 38 & 0.601 & 21 & 0.044 & 0.060 & 38 & 0.603 & 20 & 0.045 \\
\hline UP-FF & 0.347 & 14 & 0.696 & 18 & 0.289 & 0.381 & 13 & 0.704 & 17 & 0.296 \\
\hline UP-FEC & 0.143 & 29 & 0.673 & 19 & 0.115 & 0.143 & 29 & 0.673 & 18 & 0.115 \\
\hline UP-FPCE & 0.281 & 18 & 0.726 & 17 & 0.246 & 0.283 & 20 & 0.733 & 16 & 0.236 \\
\hline UP-FA & 0.309 & 16 & 0.794 & 15 & 0.266 & 0.309 & 17 & 0.794 & 14 & 0.266 \\
\hline UP-FCDEF & 0.343 & 15 & 0.797 & 14 & 0.316 & 0.325 & 16 & 0.800 & 13 & 0.288 \\
\hline UP-ICBAS & 0.279 & 19 & 0.781 & 16 & 0.263 & 0.287 & 19 & 0.790 & 15 & 0.263 \\
\hline UP-FMD & 0.889 & 6 & 0.917 & 9 & 0.854 & 0.911 & 5 & 0.914 & 8 & 0.861 \\
\hline UP-FBA & 0.350 & 13 & 0.903 & 10 & 0.343 & 0.364 & 14 & 0.903 & 10 & 0.354 \\
\hline UP-FCNA & 1.000 & 1 & 1.000 & 1 & 1.000 & 1.000 & 1 & 1.000 & 1 & 1.000 \\
\hline UTL-IST & 0.038 & 42 & 0.822 & 13 & 0.036 & 0.037 & 43 & 0.822 & 12 & 0.035 \\
\hline UTL-ISEG & 0.193 & 26 & 0.868 & 12 & 0.108 & 0.202 & 26 & 0.868 & 11 & 0.106 \\
\hline UTL-ISA & 0.298 & 17 & 0.903 & 11 & 0.195 & 0.304 & 18 & 0.905 & 9 & 0.200 \\
\hline UTL-FMV & 1.000 & 1 & 1.000 & 1 & 0.797 & 1.000 & 1 & 1.000 & 1 & 0.841 \\
\hline UTL-ISCSP & 0.809 & 7 & 0.965 & 8 & 0.198 & 0.809 & 7 & 0.965 & 7 & 0.198 \\
\hline UTL-FA & 0.688 & 10 & 0.972 & 7 & 0.190 & 0.720 & 11 & 0.974 & 6 & 0.200 \\
\hline UTL-FMH & 1.000 & 1 & 1.000 & 1 & 0.286 & 1.000 & 1 & 1.000 & 1 & 0.242 \\
\hline UTAD & 0.431 & 12 & 0.978 & 6 & 0.049 & 0.468 & 12 & 0.978 & 5 & 0.050 \\
\hline ISCTE & 1.000 & 1 & 1.000 & 1 & 0.072 & 1.000 & 1 & 1.000 & 1 & 0.069 \\
\hline Average & 0.340 & & 0.560 & & 0.193 & 0.348 & & 0.552 & & 0.190 \\
\hline
\end{tabular}

Notes: CRS TE - constant returns to scale technical efficiency.

VRS TE - variable returns to scale technical efficiency.

* Postgraduate enrolment only includes Masters' courses. 
Since graduation courses and the related number of students play a different role among the several universities, we also tried to take that information into account in our computations. Therefore, alternative results are also presented in Table 4, where we include both graduate and postgraduate students (only Masters' courses).

The results show that using graduate students as the quantitative output measure, the efficient frontier is defined by five Institutes/Faculties: UNL-ISEGI, UP-FCNA, UTLFMV, UTL-FMH, and ISCTE. Considering both graduate and postgraduate students, one of the institutes is dropped from the efficient frontier.

Taking into account only the graduate students, Table 4 also shows that input efficiency scores start at 0.019 (UMI) and output efficiency scores at 0.023 (UA). Overall, average input efficiency is around 0.34 implying that on average the faculties/institutes/universities in our sample might be able to achieve the same level of performance (i.e. have the same number of students) using only 34 per cent of the resources that they were using. In other words, there seems to be a "waste" of input resources of around 66 per cent on average. These values are similar if one considers both graduate and postgraduate students.

The scope for input efficiency improvement is quite large since for some universities the input efficiency score is quite below the average score (for instance, UA, UAV, UC-FCT, UL-FC, UMI, UNL-FCT, UP-FE, and UTL-IST). Nevertheless, one has to be careful when assessing these results since we are only measuring efficiency by using the number of students as the final output. Additional measures of efficiency, besides quantitative output measures, would imply using qualitative variables such as graduation rates and/or average grades per faculty. Unfortunately these data are not available from unified sources or from the universities themselves for that matter.

The average output efficiency score, for instance for graduation students, implies that with given public expenditures, output efficiency is 56 percent (or 44 percent less) of what it could be if the faculties/institutes/universities were on the production possibility frontier (and more if the DMUs on the production possibility frontier also have scope for expenditure savings). 
Table 5 - DEA results for tertiary education efficiency in Portugal, 2 inputs (total expenditures in 2001, and number of teachers in 2001) and 1 output (enrolment rate, 2001), only Faculties and Institutes

\begin{tabular}{|c|c|c|c|c|c|c|c|c|c|c|}
\hline \multirow{3}{*}{$\begin{array}{c}\text { University/ } \\
\text { Faculty/ } \\
\text { Institute }\end{array}$} & \multicolumn{5}{|c|}{ Enrolment: graduates } & \multicolumn{5}{|c|}{ Enrolment: graduates and postgraduates * } \\
\hline & \multicolumn{2}{|c|}{ Input oriented } & \multicolumn{2}{|c|}{ Output oriented } & \multirow[t]{2}{*}{ CRS TE } & \multicolumn{2}{|c|}{ Input oriented } & \multicolumn{2}{|c|}{ Output oriented } & \multirow[t]{2}{*}{ CRS TE } \\
\hline & VRS TE & Rank & VRS TE & Rank & & VRS TE & Rank & VRS TE & Rank & \\
\hline UC-FCT & 0.039 & 35 & 0.028 & 36 & 0.001 & 0.043 & 35 & 0.028 & 36 & 0.001 \\
\hline UL-FL & 0.061 & 31 & 0.056 & 35 & 0.004 & 0.061 & 31 & 0.056 & 35 & 0.004 \\
\hline UL-FD & 0.150 & 26 & 0.083 & 34 & 0.016 & 0.150 & 26 & 0.083 & 34 & 0.016 \\
\hline UL-FM & 0.237 & 23 & 0.113 & 33 & 0.037 & 0.264 & 20 & 0.114 & 33 & 0.036 \\
\hline UL-FC & 0.050 & 34 & 0.139 & 32 & 0.009 & 0.054 & 34 & 0.139 & 32 & 0.009 \\
\hline UL-FF & 0.239 & 22 & 0.168 & 31 & 0.052 & 0.260 & 21 & 0.171 & 31 & 0.054 \\
\hline UL-FPCE & 0.263 & 19 & 0.201 & 30 & 0.067 & 0.260 & 22 & 0.203 & 30 & 0.063 \\
\hline UL-FMD & 0.631 & 10 & 0.253 & 29 & 0.198 & 0.757 & 8 & 0.253 & 29 & 0.209 \\
\hline UL-FBA & 0.254 & 21 & 0.272 & 28 & 0.079 & 0.254 & 23 & 0.272 & 28 & 0.079 \\
\hline UNL-FCT & 0.051 & 33 & 0.278 & 27 & 0.019 & 0.057 & 33 & 0.278 & 27 & 0.020 \\
\hline UNL-FCSH & 0.069 & 30 & 0.306 & 26 & 0.026 & 0.065 & 30 & 0.306 & 26 & 0.025 \\
\hline UNL-FD & 0.787 & 7 & 0.409 & 23 & 0.326 & 0.787 & 7 & 0.409 & 23 & 0.326 \\
\hline UNL-FE & 0.183 & 25 & 0.361 & 25 & 0.085 & 0.189 & 25 & 0.361 & 25 & 0.085 \\
\hline UNL-FCM & 0.277 & 18 & 0.401 & 24 & 0.152 & 0.332 & 13 & 0.407 & 24 & 0.160 \\
\hline UNL-ISEGI & 1.000 & 1 & 1.000 & 1 & 0.588 & 0.890 & 5 & 0.504 & 21 & 0.460 \\
\hline UP-FL & 0.075 & 29 & 0.444 & 22 & 0.041 & 0.075 & 29 & 0.444 & 22 & 0.041 \\
\hline UP-FD & 0.746 & 8 & 0.577 & 18 & 0.437 & 0.746 & 9 & 0.577 & 17 & 0.437 \\
\hline UP-FM & 0.260 & 20 & 0.510 & 21 & 0.178 & 0.269 & 19 & 0.514 & 20 & 0.167 \\
\hline UP-FC & 0.079 & 28 & 0.528 & 20 & 0.054 & 0.082 & 28 & 0.528 & 19 & 0.054 \\
\hline UP-FE & 0.055 & 32 & 0.556 & 19 & 0.041 & 0.060 & 32 & 0.556 & 18 & 0.041 \\
\hline UP-FF & 0.347 & 12 & 0.632 & 16 & 0.269 & 0.381 & 11 & 0.640 & 15 & 0.276 \\
\hline UP-FEC & 0.143 & 27 & 0.611 & 17 & 0.109 & 0.143 & 27 & 0.611 & 16 & 0.109 \\
\hline UP-FPCE & 0.281 & 16 & 0.670 & 15 & 0.234 & 0.283 & 18 & 0.678 & 14 & 0.225 \\
\hline UP-FA & 0.309 & 14 & 0.748 & 13 & 0.255 & 0.309 & 15 & 0.748 & 12 & 0.255 \\
\hline UP-FCDEF & 0.343 & 13 & 0.754 & 12 & 0.307 & 0.325 & 14 & 0.757 & 11 & 0.280 \\
\hline UP-ICBAS & 0.279 & 17 & 0.737 & 14 & 0.257 & 0.287 & 17 & 0.747 & 13 & 0.258 \\
\hline UP-FMD & 0.889 & 5 & 0.898 & 7 & 0.842 & 0.911 & 4 & 0.894 & 6 & 0.848 \\
\hline UP-FBA & 0.350 & 11 & 0.881 & 9 & 0.341 & 0.364 & 12 & 0.881 & 8 & 0.352 \\
\hline UP-FCNA & 1.000 & 1 & 1.000 & 1 & 1.000 & 1.000 & 1 & 1.000 & 1 & 1.000 \\
\hline UTL-IST & 0.038 & 36 & 0.833 & 11 & 0.036 & 0.037 & 36 & 0.833 & 10 & 0.036 \\
\hline UTL-ISEG & 0.193 & 24 & 0.861 & 10 & 0.109 & 0.202 & 24 & 0.861 & 9 & 0.108 \\
\hline UTL-ISA & 0.298 & 15 & 0.889 & 8 & 0.199 & 0.304 & 16 & 0.889 & 7 & 0.204 \\
\hline UTL-FMV & 1.000 & 1 & 1.000 & 1 & 0.816 & 1.000 & 1 & 1.000 & 1 & 0.861 \\
\hline UTL-ISCSP & 0.809 & 6 & 0.958 & 6 & 0.204 & 0.809 & 6 & 0.958 & 5 & 0.204 \\
\hline UTL-FA & 0.688 & 9 & 0.972 & 5 & 0.197 & 0.720 & 10 & 0.972 & 4 & 0.207 \\
\hline UTL-FMH & 1.000 & 1 & 1.000 & 1 & 0.298 & 1.000 & 1 & 1.000 & 1 & 0.252 \\
\hline Average & 0.374 & & 0.559 & & 0.219 & 0.381 & & 0.546 & & 0.216 \\
\hline
\end{tabular}

Notes: CRS TE - constant returns to scale technical efficiency.

VRS TE - variable returns to scale technical efficiency.

* Postgraduate enrolment only includes Masters' courses.

As already mentioned, we should have DMUs as homogeneous as possible. This is clearly not the case since so far we are using aggregate data for some Universities in some cases and we also use data on a Faculty basis. Therefore, in a second step, we 
excluded 9 DMUs from our data sample, the ones were only aggregated data is available, leaving us now with 36 units. We report the results for this smaller and more homogeneous data set in Table 5 taking into account only the graduate students and both the graduate and postgraduate students (again, only Masters courses).

With this smaller sample the efficient frontier is now defined by four Institutes/Faculties when only graduate students are used: UNL-ISEGI, UP-FCNA, UTL-FMV, and UTL-FMH, with ISCTE being absent from the sample altogether. When both graduate and postgraduate students are taken into account, three Institutes/Faculties only define the efficient frontier: UP-FCNA, UTL-FMV, and UTL-FMH. Now input efficiency scores start at 0.038 (UTL-IST) and output efficiency scores at 0.028 (UC-FCT). This picture does not change when postgraduate students are taken into account.

The ranking of the Faculties/Institutes also remains rather stable either using only graduate or both graduate and postgraduate students. Nevertheless, perhaps one could mention that UNL-FCM increases its input efficiency ranking by five places and that UNL-ISEGI also drops five places in terms of the input efficiency ranking (the decline is much higher in the output efficiency ranking).

The overage input and output efficiency scores are now a little higher than when the aggregated universities data were used. Still, average input efficiency is around 0.374 implying that on average the faculties/institutes in the sample might be able to achieve a similar level of performance using only 37.4 per cent of the resources that they were using. Again, there seems to be a significant amount of "wasted" input resources of around 62.6 per cent on average.

\subsection{Further sub-group analysis}

Due to the already mentioned limitations of the available data, and in order to achieve a more homogeneous data set, we excluded from the last sample of 36 DMUs (used in Table 5) the Faculties that were quite far from the mean values in terms of per student ratios. For instance, while for the aforementioned sample there was in 2001 an average of 9.5 teachers per 100 students, some faculties had rather different (lower) 
numbers. Therefore, we excluded those faculties where this ratio was at least 50 per cent higher than the average value. This procedure led us to identify, and detach from the sample, seven faculties where the teachers per 100 students ratio ranged from 14.5 (UP-FMD) to 33.2 (UNL-FCM). In other words, those seven faculties had a studentsto-teachers ratio between 3 (UNL-FCM) and 7 (UP-FMD) while the average in the entire sample was around 11 students per teacher.

The analysis of the smaller group of seven faculties, excluded from the main sample, it is possible to see that it is composed of the entire sub-sample of medical faculties (UL-FM, UL-FMD, UNL-FCM, UP-FM, UP-ICBAS, UP-FMD, UTL-FMD). In addition, this exclusion seems reasonable. First, those faculties do have rather more demanding courses both in terms of teachers per student ratios and regarding financial requirements. Even if there must be some positive correlation between the number of teachers and total spending, one has to notice that in 2001 the spending ratio of those faculties ranged from 8921 euros per student (UL-FM) to 18847 euros per student (UTL-FMD), when the average for the entire sample was 5698 euros. Secondly, this allows us to assess separately the performance of a more similar a smaller sub-group of faculties: medical faculties.

In Table 6 we report the results of the DEA analysis for the sub-sample of 29 Faculties/Institutes, considering graduate and postgraduate students together, and where the medical faculties are now excluded. 
Table 6 - DEA results for tertiary education efficiency in Portugal, 2 inputs (total expenditures in 2001, and number of teachers in 2001) and 1 output (enrolment rate, 2001), only Faculties and Institutes, medical Faculties not included

\begin{tabular}{|c|c|c|c|c|c|}
\hline \multirow{3}{*}{$\begin{array}{l}\text { University/ } \\
\text { Faculty/ } \\
\text { Institute }\end{array}$} & \multicolumn{5}{|c|}{ Enrolment: graduates and postgraduates * } \\
\hline & \multicolumn{2}{|c|}{ Input oriented } & \multicolumn{2}{|c|}{ Output oriented } & \multirow[t]{2}{*}{ CRS TE } \\
\hline & VRS TE & Rank & VRS TE & Rank & \\
\hline UC-FCT & 0.043 & 29 & 0.028 & 29 & 0.001 \\
\hline UL-FL & 0.061 & 24 & 0.056 & 28 & 0.004 \\
\hline UL-FD & 0.150 & 19 & 0.083 & 27 & 0.016 \\
\hline UL-FC & 0.054 & 27 & 0.139 & 26 & 0.009 \\
\hline UL-FF & 0.260 & 14 & 0.176 & 25 & 0.054 \\
\hline UL-FPCE & 0.260 & 15 & 0.205 & 24 & 0.063 \\
\hline UL-FBA & 0.254 & 16 & 0.272 & 23 & 0.079 \\
\hline UNL-FCT & 0.057 & 26 & 0.278 & 22 & 0.020 \\
\hline UNL-FCSH & 0.065 & 23 & 0.306 & 21 & 0.025 \\
\hline UNL-FD & 0.787 & 5 & 0.409 & 19 & 0.326 \\
\hline UNL-FE & 0.189 & 18 & 0.361 & 20 & 0.085 \\
\hline UNL-ISEGI & 0.890 & 3 & 0.513 & 17 & 0.460 \\
\hline UP-FL & 0.075 & 22 & 0.444 & 18 & 0.041 \\
\hline UP-FD & 0.746 & 7 & 0.577 & 14 & 0.437 \\
\hline UP-FC & 0.082 & 21 & 0.528 & 16 & 0.054 \\
\hline UP-FE & 0.060 & 25 & 0.556 & 15 & 0.041 \\
\hline UP-FF & 0.381 & 9 & 0.658 & 12 & 0.276 \\
\hline UP-FEC & 0.143 & 20 & 0.611 & 13 & 0.109 \\
\hline UP-FPCE & 0.283 & 13 & 0.686 & 11 & 0.225 \\
\hline UP-FA & 0.309 & 12 & 0.748 & 10 & 0.255 \\
\hline UP-FCDEF & 0.325 & 11 & 0.764 & 9 & 0.280 \\
\hline UP-FBA & 0.364 & 10 & 0.881 & 6 & 0.352 \\
\hline UP-FCNA & 1.000 & 1 & 1.000 & 1 & 1.000 \\
\hline UTL-IST & 0.054 & 28 & 0.833 & 8 & 0.036 \\
\hline UTL-ISEG & 0.214 & 17 & 0.861 & 7 & 0.108 \\
\hline UTL-ISA & 0.496 & 8 & 0.889 & 5 & 0.204 \\
\hline UTL-ISCSP & 0.809 & 4 & 0.958 & 4 & 0.204 \\
\hline UTL-FA & 0.750 & 6 & 0.972 & 3 & 0.207 \\
\hline UTL-FMH & 1.000 & 1 & 1.000 & 1 & 0.252 \\
\hline Average & 0.350 & & 0.545 & & 0.219 \\
\hline
\end{tabular}

Notes: CRS TE - constant returns to scale technical efficiency. VRS TE - variable returns to scale technical efficiency.

* Postgraduate enrolment only includes Masters' courses.

From the results of Table 6, one can conclude that the efficient DMUs are now two: UP-FCNA and UTL-FMH. Indeed, UP-FCNA had a ratio of spending to students quite below the average, even if its ratio of teachers per 100 students was slightly above average. On the other hand, UTL-FMH had an average teachers-to-100 students ratio and exhibited below average spending per student. Additionally, input efficiency is rather similar to the results reported in Tables 4 and 5. 
Taking advantage of the smaller sub-sample of seven medical faculties/institutes, we performed a similar DEA analysis for those DMUs, and the results are presented in Table 7.

Table 7 - DEA results for tertiary education efficiency in Portugal, 2 inputs (total expenditures in 2001, and number of teachers in 2001) and 1 output (enrolment rate, 2001), only medical Faculties

\begin{tabular}{|c|c|c|c|c|c|}
\hline \multirow{3}{*}{$\begin{array}{l}\text { University/ } \\
\text { Faculty/ } \\
\text { Institute }\end{array}$} & \multicolumn{5}{|c|}{ Enrolment: graduates and postgraduates * } \\
\hline & \multicolumn{2}{|c|}{ Input oriented } & \multicolumn{2}{|c|}{ Output oriented } & \multirow[t]{2}{*}{ CRS TE } \\
\hline & VRS TE & Rank & VRS TE & Rank & \\
\hline UL-FM & 0.304 & 6 & 0.143 & 7 & 0.051 \\
\hline UL-FMD & 0.830 & 3 & 0.310 & 6 & 0.277 \\
\hline UNL-FCM & 0.364 & 4 & 0.429 & 5 & 0.182 \\
\hline UP-FM & 0.295 & 7 & 0.571 & 4 & 0.197 \\
\hline UP-ICBAS & 0.315 & 5 & 0.714 & 3 & 0.263 \\
\hline UP-FMD & 1.000 & 1 & 1.000 & 1 & 1.000 \\
\hline UTL-FMD & 1.000 & 1 & 1.000 & 1 & 0.969 \\
\hline Average & 0.587 & & 0.595 & & 0.420 \\
\hline
\end{tabular}

Notes: CRS TE - constant returns to scale technical efficiency. VRS TE - variable returns to scale technical efficiency.

* Postgraduate enrolment only includes Masters' courses.

From Table 7 it is possible to conclude that the efficient medical DMUs are UP-FMD and UTL-FMD. Those two DMUs had in 2001 the two lowest teachers per 100 students ratios (conversely the two highest students-to-teachers ratios). Moreover, while UP-FMD is the peer for all the other five faculties outside the production possibility frontier. Interestingly, one may also notice that now input efficiency is higher, and around 58.7 per cent, for this sub-sample of faculties/institutes, giving a measure of a smaller degree of overall "wasted" inputs than before. This implies that, as mentioned previously, more detailed data would be welcomed in order to better characterise the distinctiveness of each faculty due to the fact that their courses might be quite diverse.

Nevertheless, the result for the medical faculties/institutes sub-sample has to be seen with some caution, since we used a quite small number of DMUs, seven, and three variables has output and inputs. See footnote 14 about the risk of having fewer degrees of freedom in the context of DEA analysis. Furthermore, this constraint prevented us from performing similar analysis for say Law faculties (three in the sample) or Economics faculties (three in the sample). 
Finally, we summarise in Table 8 the main findings of our non-parametric analysis, performed for the various sub-samples of Universities/Faculties/ Institutes.

Table 8 - Efficient public Universities/Faculties/Institutes: summary of DEA results

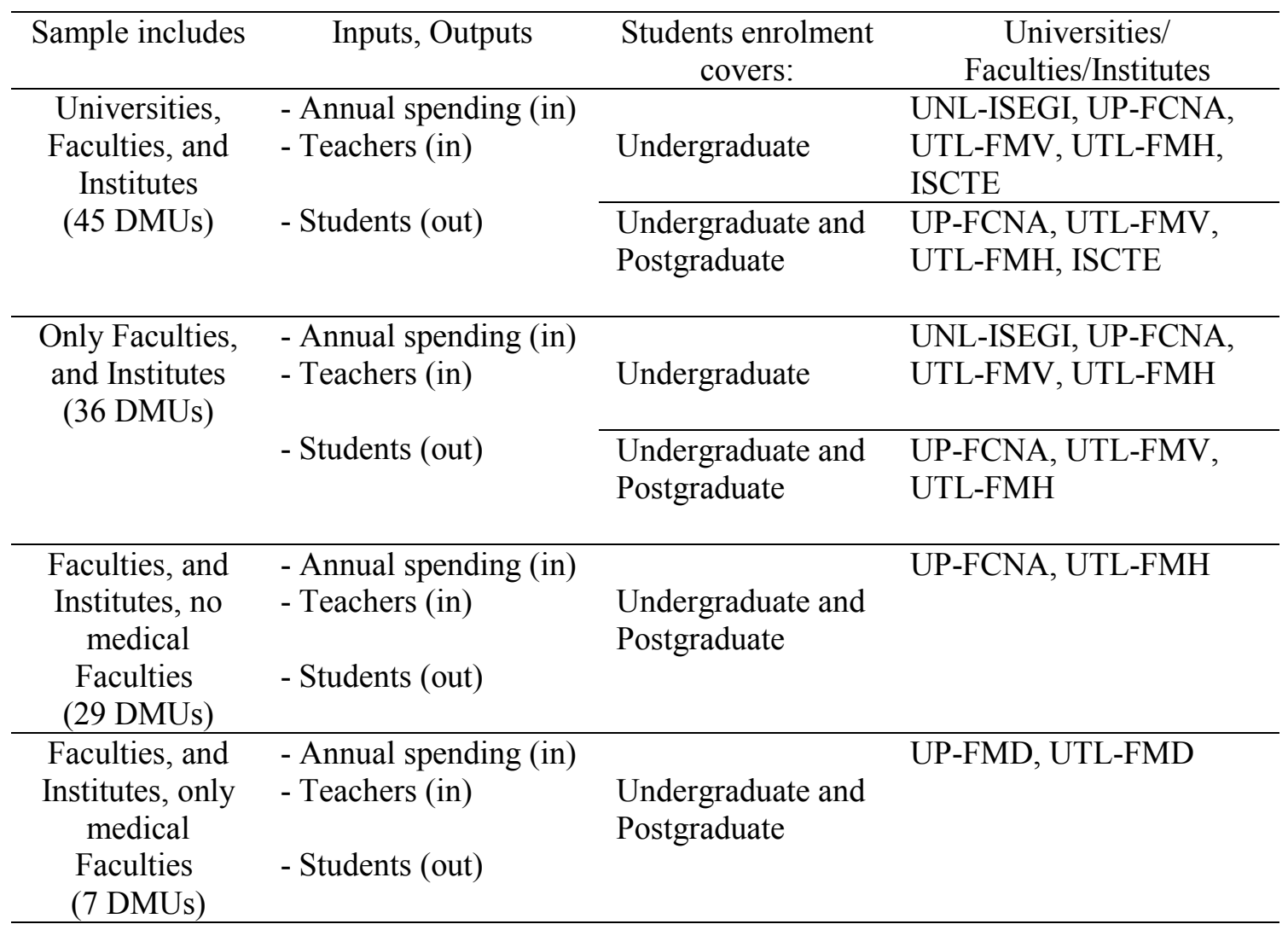

\section{Conclusion}

The results from our empirical work in evaluating efficiency in Portuguese public universities allowed us to compute efficiency scores for each Faculty/Institute in producing tertiary education, including estimates of efficiency losses, and to construct rankings of the Faculties/Institutes, including therefore the identification of the most efficient cases.

The efficient DMUs are located across Universities and across courses. Considering graduates students as the quantitative output measure, input efficiency is around 0.34 implying that on average the faculties/institutes/universities in our sample might be able to achieve the same level of performance using only 34 per cent of the resources 
that they were using. In other words, there seems to be a "waste" of input resources of around 66 per cent on average. Efficiency scores increase (input efficiency is around 37.4 per cent) when both graduate and postgraduate students are used as the output measure. Similarly, dropping from our sample the Universities were we only have aggregate data (and no information by Faculty/Institute) also increases the efficiency scores.

The results with a more homogeneous sub-group of faculties, excluding DMUs with spending and/or teachers' ratios very different from the average (i. e. medical faculties), produced similar results, even if some changes occurred in the ordering. Additionally, results were also reported for the seven medical faculties sub-sample, with UP-FMD, UTL-FMD coming out as the efficient DMUs, and with an overall input efficiency of 58.7 per cent.

Again and as previously mentioned, our results must be seen as a first attempt to assess the efficiency of public tertiary education expenditure in Portugal, and the conclusions drawn upon those results must be read with care. A richer dataset, comprising the performance of students, and also the possibility of using other Universities' outputs, such as research activities, would be an important improvement for this analysis. Furthermore, one has to be aware that simply putting more money into a promising activity, i.e. tertiary education, does not necessarily improve output quality proportionally. Nevertheless, we did not address in this paper schooling quality as an output, since such homogeneous data is not publicly available and it proved rather difficult to gather for a sufficient number of Universities. 


\section{Annex - Data and sources}

Table 1 - List of Universities, Faculties and Institutes

\begin{tabular}{|c|c|c|}
\hline CODE & FACULTY / INSTITUTE /UNIVERSITY & No \\
\hline$U A$ & UNIVERSIDADE DOS AÇORES & \\
\hline$U A L$ & UNIVERSIDADE DO ALGARVE & \\
\hline$U A V$ & UNIVERSIDADE DE AVEIRO & \\
\hline$U B I$ & UNIVERSIDADE DA BEIRA INTERIOR & 4 \\
\hline UC-FCT & UNIVERSIDADE DE COIMBRA - FACULDADE DE CIÊNCIAS E TECNOLOGIA & \\
\hline$E U$ & UNIVERSIDADE DE ÉVORA & \\
\hline UL-FL & UNIVERSIDADE DE LISBOA - FACULDADE DE LETRAS & \\
\hline UL-FD & UNIVERSIDADE DE LISBOA - FACULDADE DE DIREITO & \\
\hline UL-FM & UNIVERSIDADE DE LISBOA - FACULDADE DE MEDICINA & \\
\hline UL-FC & UNIVERSIDADE DE LISBOA - FACULDADE DE CIÊNCIAS & 10 \\
\hline UL-FF & UNIVERSIDADE DE LISBOA - FACULDADE DE FARMÁCIA & 11 \\
\hline UL-FPCE & UNIV. DE LISBOA - FACULDADE DE PSICOLOGIA E CIÊNCIAS DA EDUCAÇÃO & 12 \\
\hline UL-FMD & UNIVERSIDADE DE LISBOA - FACULDADE DE MEDICINA DENTÁRIA & 13 \\
\hline UL-FBA & UNIVERSIDADE DE LISBOA - FACULDADE DE BELAS ARTES & 14 \\
\hline$U M$ & UNIVERSIDADE DA MADEIRA & 15 \\
\hline UMI & UNIVERSIDADE DO MINHO & 16 \\
\hline UNL-FCT & UNIVERSIDADE NOVA DE LISBOA - FACULDADE DE CIÊNCIAS E TECNOLC & 17 \\
\hline UNL-FCSH & UNIV. NOVA DE LISBOA - FACULDADE DE CIÊNCIAS SOCIAIS E HUMANAS & 18 \\
\hline UNL-FD & UNIVERSIDADE NOVA DE LISBOA - FACULDADE DE DIREITO & 19 \\
\hline UNL-FE & UNIVERSIDADE NOVA DE LISBOA - FACULDADE DE ECONOMIA & 20 \\
\hline UNL-FCM & UNIVERSIDADE NOVA DE LISBOA - FACULDADE DE CIENCIAS MÉDICAS & 21 \\
\hline UNL-ISEGI & UNIV. NOVA LISBOA - INST. SUPERIOR ESTATÍSTICA E GESTÃO DA INFORMAÇÃO & 22 \\
\hline UP-FL & UNIVERSIDADE DO PORTO - FACULDADE DE LETRAS & 23 \\
\hline UP-FD & UNIVERSIDADE DO PORTO - FACULDADE DE DIREITO & 24 \\
\hline UP-FM & UNIVERSIDADE DO PORTO - FACULDADE DE MEDICINA & 25 \\
\hline UP-FC & UNIVERSIDADE DO PORTO - FACULDADE DE CIÊNCIAS & 26 \\
\hline UP-FE & UNIVERSIDADE DO PORTO - FACULD & 27 \\
\hline UP-FF & UNIVERSIDADE DO PORTO - FACULDADE DE FARMÁCIA & 28 \\
\hline UP-FEC & UNIVERSIDADE DO PORTO - FACULDADE DE ECONOMIA & 29 \\
\hline UP-FPCE & UNIV. DO PORTO - FACULDADE DE PSICOLOGIA E CIÊNCIAS DA EDUCAÇÃO & 30 \\
\hline UP-FA & UNIVERSIDADE DO PORTO - FACULDADE DE ARQUITECTURA & 31 \\
\hline UP-FCDEF & UNIV. DO PORTO - FACULDADE CIÊNCIAS DO DESPORTO E EDUCAÇÃO FÍSICA & 32 \\
\hline UP-ICBAS & UNIV. DO PORTO - INSTITUTO DE CIÊNCIAS BIOMÉDICAS DE ABEL SALAZAR & 33 \\
\hline UP-FMD & UNIVERSIDADE DO PORTO - FACULDADE DE MEDICINA DENTÁRIA & 34 \\
\hline UP-FBA & UNIVERSIDADE DO PORTO - FACULDA & 35 \\
\hline UP-FCNA & UNIV. DO PORTO - FACULDADE DE CIÊNCIAS DA NUTRIÇÃO E ALIMENTAÇÃO & 36 \\
\hline UTL-IST & UNIV. TÉCNICA DE LISBOA - INSTITUTO SUPERIOR TÉCNICO & 37 \\
\hline UTL-ISEG & UNIV. TÉCNICA DE LISBOA - INSTITUTO SUPERIOR DE ECONC & 38 \\
\hline UTL-ISA & UNIV. TÉCNICA DE LISBOA - INSTITUTO SUPERIOR DE AGRONOMIA & 39 \\
\hline UTL-FMV & UNIV. TÉCNICA DE LISBOA - FACULDADE DE MEDICINA VETERINÁRIA & 40 \\
\hline UTL-ISCSP & UNIV. TÉCNICA LISBOA - INST.SUPERIOR CIÊNCIAS SOCIAIS POLÍTICA & 41 \\
\hline UTL-FA & UNIV. TÉCNICA DE LISBOA - FACULDADE DE ARQUITECTURA & 42 \\
\hline UTL-FMH & UNIV. TÉCNICA DE LISBOA - FACULDADE DE MOTRICIDADE HUMANA & 43 \\
\hline UTAD & UNIVERSIDADE DE TRÁS-OS-MONTES E ALTO DOURO & 44 \\
\hline ISCTE & INSTITUTO SUPERIOR DE CIENNCIAS DO TRABALHO E DA EMPRESA & 45 \\
\hline
\end{tabular}

Note: In italics, Universities where no disaggregate data by Faculty/Institute were available. These DMUs were not included in the calculations for Tables 5 and 6. 
Table 2 - Original data set

\begin{tabular}{|c|c|c|c|c|}
\hline \multirow{2}{*}{$\begin{array}{l}\text { Univ./ Fac./Inst. } \\
\text { Code }\end{array}$} & \multicolumn{2}{|c|}{ Students enrolment (2001) 1/ } & \multirow{2}{*}{$\begin{array}{c}\text { Total } \\
\text { expenditures } \\
2001 \text { (euro) 2/ }\end{array}$} & \multirow{2}{*}{$\begin{array}{c}\text { Teachers, } \\
2001 * \\
3 / \\
\end{array}$} \\
\hline & Graduates & $\begin{array}{l}\text { Graduates and } \\
\text { postgraduates }\end{array}$ & & \\
\hline$\overline{\mathrm{UA}}$ & 2928 & 3001 & 23037550 & 269 \\
\hline UAL & 4404 & 4563 & 48468391 & 383 \\
\hline UAV & 8307 & 8534 & 60892803 & 703 \\
\hline UBI & 4521 & 4687 & 27418237 & 389 \\
\hline UC-FCT & 7022 & 7237 & 41931630 & 656 \\
\hline UE & 7606 & 7856 & 41971908 & 621 \\
\hline UL-FL & 5013 & 5392 & 19035355 & 367 \\
\hline UL-FD & 3523 & 3620 & 7729307 & 231 \\
\hline UL-FM & 1086 & 1166 & 10401847 & 325 \\
\hline UL-FC & 5359 & 5670 & 37970711 & 509 \\
\hline UL-FF & 1153 & 1183 & 7175048 & 126 \\
\hline UL-FPCE & 1059 & 1186 & 6032432 & 117 \\
\hline UL-FMD & 407 & 407 & 5164668 & 107 \\
\hline UL-FBA & 1179 & 1226 & 4568066 & 91 \\
\hline UM & 2261 & 2329 & 14955308 & 191 \\
\hline UMI & 15236 & 15580 & 76336534 & 1207 \\
\hline UNL-FCT & 5312 & 5440 & 36447068 & 501 \\
\hline UNL-FCSH & 4182 & 4703 & 17701120 & 349 \\
\hline UNL-FD & 528 & 528 & 1470755 & 17 \\
\hline UNL-FE & 1547 & 1628 & 7818103 & 107 \\
\hline UNL-FCM & 929 & 929 & 8791707 & 308 \\
\hline UNL-ISEGI & 257 & 346 & 2301149 & 25 \\
\hline UP-FL & 4313 & 4471 & 15464251 & 290 \\
\hline UP-FD & 553 & 553 & 1552314 & 29 \\
\hline UP-FM & 1019 & 1145 & 13132276 & 247 \\
\hline UP-FC & 3516 & 3739 & 20758687 & 311 \\
\hline UP-FE & 4966 & 5176 & 33649864 & 445 \\
\hline UP-FF & 786 & 809 & 5188730 & 66 \\
\hline UP-FEC & 2599 & 2754 & 8097400 & 164 \\
\hline UP-FPCE & 989 & 1087 & 5717266 & 91 \\
\hline UP-FA & 1032 & 1032 & 3753933 & 69 \\
\hline UP-FCDEF & 821 & 949 & 4845921 & 79 \\
\hline UP-ICBAS & 1019 & 1072 & 10294221 & 275 \\
\hline UP-FMD & 323 & 338 & 3159336 & 49 \\
\hline UP-FBA & 827 & 846 & 3503826 & 71 \\
\hline UP-FCNA & 292 & 308 & 1158139 & 30 \\
\hline UTL-IST & 8336 & 8954 & 78561776 & 945 \\
\hline UTL-ISEG & 2858 & 3056 & 15016969 & 256 \\
\hline UTL-ISA & 1619 & 1668 & 17667591 & 171 \\
\hline UTL-FMV & 407 & 407 & 7670783 & 75 \\
\hline UTL-ISCSP & 2870 & 3046 & 6664065 & 182 \\
\hline UTL-FA & 1793 & 1793 & 9059836 & 193 \\
\hline UTL-FMH & 1218 & 1518 & 7083544 & 122 \\
\hline UTAD & 7310 & 7567 & 39847627 & 599 \\
\hline ISCTE & 5085 & 5561 & 27149136 & 436 \\
\hline Average & 3039 & 3186 & 18813715 & 284 \\
\hline
\end{tabular}

1/ Direcção-Geral do Ensino Superior.

2/ Conta Geral do Estado - 2001. Direcção-Geral do Orçamento. [http://www.dgo.pt/cge/cge2001/index.htm]

3/ Direcção-Geral do Ensino Superior.

* Overall number of teachers in the following categories: full Prof. (catedrático), associate Prof. (associado), assistant Prof. (auxiliar), teaching assistant (assistente), trainee teaching assistant (assistente estagiário), and others (leitor, monitor). 


\section{References}

Blanchard, O. (2004). "The Economic Future of Europe.” NBER Working Paper 10310 , February.

Afonso, A.; Schuknecht, L. and Tanzi, V. (2003). "Public Sector Efficiency: An International Comparison," ECB Working Paper 242, July (Public Choice, forthcoming).

Afonso, A. and St. Aubyn, M. (2004). "Non-parametric Approaches to Public Education and Health Expenditure Efficiency in OECD countries." ISEG/UTLTechnical University of Lisbon, Economics Department, Working Paper 1/2004/DE/CISEP/UECE.

Athans, M. (2002). "Portuguese Research Universities: why not the Best?" Economia Global e Gestão, 7 (1), 121-139.

Bowlin, W. (1998). "Measuring Performance: An Introduction to Data Envelopment analysis (DEA)." Journal of Cost Analysis, Fall, 3-27.

Charnes, A.; Cooper, W. and Rhodes, E. (1978). "Measuring the efficiency of decision making units," European Journal of Operational Research, 2 (6), 429-444.

Clements, B. (2002). "How Efficient is Education Spending in Europe?" European Review of Economics and Finance, 1 (1), 3-26.

Coelli, T. (1996). "Assessing the Performance of Australian Universities using Data Envelopment Analysis," mimeo, University of New England.

Coelli, T.; Rao, P. and Battese, G. (1998). An Introduction to Efficiency and Productivity Analysis, Kluwer, Boston.

De Borger, B. and Kerstens, K. (1996). "Cost Efficiency of Belgian Local Governments: A Comparative Analysis of FDH, DEA, and Econometric Approaches," Regional Science and Urban Economics, 26 (2), 145-170.

Deprins, D.; Simar, L., and Tulkens, H. (1984). "Measuring labor-efficiency in post offices," in: Marchand, M.; Pestieau, P. and Tulkens, H. (Eds.), The performance of public enterprises: concepts and measurement. Amsterdam: North-Holland.

Eurostat (2002). “Key Data on Education in Europe 2002”, European Commission.

Fakin, B. and de Crombrugghe, A. (1997). "Fiscal adjustment in transition economies: social transfers and the efficiency of public spending: a comparison with OECD countries," Policy Research Working Paper 1803. Washington, DC: World Bank.

Farrell, M. (1957). "The Measurement of Productive Efficiency," Journal of the Royal Statistical Society, Series A, 120, Part 3, 253-290. 
Førsund, F. and Kalhagen, K. (1999). "Efficiency and roductivity of Norwegian Colleges," University of Oslo, Department of Economics WP 11/99.

Gupta, S. and Verhoeven, M. (2001). "The Efficiency of Government Expenditure Experiences from Africa," Journal of Policy Modeling, 23, 433-467.

Murillo-Zamorano, L. (2004). "Economic Efficiency and Frontier Techniques," Journal of Economic Surveys, 18 (1), 33-77.

Simar, L. and Wilson, P. (2003). Efficiency analysis: the statistical approach, lecture notes, July.

St. Aubyn, M. (2002). "Evaluating Efficiency in the Portuguese Health and Education Sectors," paper presented to the conference "Desenvolvimento Económico Português no Espaço Europeu: Determinantes e Políticas", Banco de Portugal, May, Fundação Calouste Gulbenkian, Lisbon.

Thanassoulis, E. (2001). Introduction to the Theory and Application of Data Envelopment Analysis, Kluwer Academic Publishers.

Tulkens, H. (1993). "On FDH analysis: some methodological issues and applications to retail banking, courts and urban transit," Journal of Productivity Analysis 4, 183210.

Vanden Eeckhaut, P., Tulkens, H., and Jamar, M.-A. (1993). "Cost-efficiency in Belgian municipalities," in Fried, H.; Lovell, C. and Schmidt, S. (eds.), The Measurement of Productive Efficiency: Techniques and Applications. New York: Oxford Univ. Press. 